\title{
LEGACY OF EMPIRES: ACADEMIC EXPERTISE AND USA POLICY IN AFGHANISTAN AND IRAQ IN 2001-2014
}

(C) 2019

\author{
Malkin Stanislav Gennadyevich, doctor of historical sciences, associate professor, \\ head of World History, Law and Methods of Teaching Department \\ Samara State University of Social Sciences and Education (Samara, Russian Federation)
}

Abstract. The heritage of the European colonial empires should be perceived as «missing dimension» while studying the history of the USA foreign policy at the beginning of the XXI century. The comparative-historical analysis as well as transfers of colonial experience of the European powers should be discussed. It promotes making a fuller picture of imperialism as a phenomenon in the history of international relations as well as a certain style of thinking during a decolonization era. At the same time the American case became the most striking example of reception of the European powers colonial experience in political practice of the $2000^{\text {th }}$. The main characteristic feature of the USA foreign policy decisions examination was its realization in the form of historical modeling of the asymmetric conflicts - the analysis of Washington policy prospects in Afghanistan and Iraq in a wide context of experience of global colonial empires. While working with such researches a constant methodological reflection caused by their political involvement as well as restrictions of disciplinary character is necessary. At the same time a special role in this case belonged to the academic world representatives who professionally studied colonial experience of the European. It is them who were the most serious competitors to the Pentagon representatives with academic degrees as well as to «think tanks» analysts who cooperated with the military in fight for their own expert opinion domination about historical modeling of the asymmetric conflicts in the Middle East. It is this aspect of the academic examination of the USA policy in Iraq and Afghanistan in 2001-2014 that the following paper deals with.

Keywords: empire; imperialism; colonial knowledge; postcolonial age; academic expertise; historical modeling; asymmetric conflict; small wars; counterinsurgency; «think tanks»; USA; Great Britain; Afghanistan; Iraq; Near and Middle East; «COIN Lobby».

\section{УДК 930.2}

\section{КЛАССОВЫЙ ПОДХОД К ПОЗНАНИЮ ИСТОРИИ БЕЗНАДЕЖНО УСТАРЕЛ? ИЛИ... (РАССУЖДЕНИЯ - ПРИГЛАШЕНИЕ К ДИСКУССИИ)}

\section{(C) 2019}

Ипполитов Георгий Михайлович, доктор исторических наук, профессор кафедры философии Поволжский государственный университет телекоммуникаций и информатики

\author{
(2. Самара, Российская Федерациия)
}

\begin{abstract}
Аннотаџия. В настоящей статье автор предпринял попытку раскрытия (в дискуссионном ключе) некоторых аспектов столь сложной и многоаспектной проблемы, как классовый подход к оценке событий и явлений в качестве одного из подходов к познанию истории. Стиль изложения - лапидарный, с элементами конспективности. Рассмотрены фундаментальные постулаты марксистско-ленинской концепции классового подхода к оценке событий и явлений в качестве одного из подходов к познанию истории. Причем, акцент сделан здесь именно на ленинское понимание методологического феномена, указанного выше, и его развитие идеологами правившей в Советском государстве коммунистической партии. Прослеживается развитие исследуемой концепции в советской исторической науке. При этом подчеркивается, что здесь допускались элементы эклектики, когда ученые путали понятия «принципы исторического исследования» и «подходы к познанию истории». Освещается, как в постсоветской и современной историографии трактуется проблема классового подхода к оценке событий и явлений в качестве одного из подходов к познанию истории. Автор обосновывается, что данный подход сегодня в исторической науке не устарел безнадежно, как считают многие представители так называемой либеральной исторической школы (с В.О. Ключевским прошу не путать), а продолжает функционировать. Правда, изменив формы проявления, и несколько отойдя на задний план.

Ключевые слова: классовый подход; К. Маркс; Ф. Энгельс; В.И. Ленин; советская историческая наука; марксизм-ленинизм; социальный подход; игра дефиниций.
\end{abstract}

«Не сознание людей определяет их бытие, а, наоборот, их общественное бытие определяет их сознание», - К. Маркс [1, т. 28, с. 7].

Мысль выдающегося немецкого мыслителя К. Маркса, приведенная выше в качестве эпиграфа, во многом выражает суть материалистического понимания истории. Того самого понимания, вокруг которого в 1990-е годы развернулась, скорее всего, даже не академическая дискуссия, а жестокая полемика, принимавшая порою характер зубодробительной. Это во 318 многом детерминировалось тем, что, во-первых, в нашей стране произошла смена цивилизационной парадигмы, что привело к переоценке ценностей, и марксизм (особенно большевистское измерение ленинизм) попал под огонь политизированной, часто уничижительной критики; во-вторых, кризисом исторической науки [2, с. 21-36; 3, с. 95-101; 4, с. 635642]. По словам выдающегося отечественного методолога исторической науки Б.Г. Могильницкого сложилось такое состояние науки, когда «старая пара- 
Ипполитов Г.М.

дигма уже разрушена, или разрушается, а новая еще не создана и в сообществе историков возникает сознание, что что-то не то, что-то не так» [5, с. 9]. Некоторые ретивые так называемые либеральные исследователи выкинули марксизм «на свалку истории», однако уподобились при этом музыкантам оркестра, занявшим места в оркестровой яме, но забывшим ноты. В итоге, погнались за новомодными парадигмами с Запада, и ...потерялись. Случилось, по меткой характеристике крупного советского/российского ученого Ю.А. Полякова, «разрушение старого и не создание нового» $[6$, с. 6$]$.

Относительно же классового подхода к оценке событий и явлений - этого родного детища марксизма и, особенно ленинизма, заметим, что ученые просто стали его дружно игнорировать в качестве составляющей методологических оснований исторических исследований. Так, автор данной статьи, проанализировав более 30 авторефератов кандидатских и более 10 авторефератов докторских диссертаций, защищенных в 1994-1998 г. по специальности 07.00.02 - отечественная история, установил: ни в одном из них классовый подход во фрагментах, посвященных методологическим основам диссертационного исследования, просто не упоминается. Понятно, что здесь мы имеем дело во многом с конъюнктурным явлением (зачем усложнять себе процедуру защиты?). И все-таки оно несет на себе, в какой-то степени, знаковый характер. Подобную «аллергию» на классовый подход можно, видимо, объяснить следующим обстоятельством: данный подход предполагал в императивном ключе обязательное выяснение и учет при анализе исторической концепции классовой позиции того или иного историка. Ведь в методологии советской исторической науке только классовый подход, помноженный на принцип коммунистической партийности, отождествлялся с научностью [7, c. 475-484]. Поэтому исследователи 1990-х годов, видимо, посчитали, что демонстрация приверженности к классовому подходу не позволяет историку быть объективным.

И хотя в процессе преодоления кризиса отечественной исторической науки, что имело место в начале XXI в., [8, с. 3-20; 9, с. 3-32], оценки здесь стали несколько корректнее (впрочем, как и всей методологии марксизма), тем не менее, и сегодня классовый подход находится в дискуссионном поле. Да и полемика тут иногда вспыхивает. Причем, полемисты утверждают, как правило, что классовый подход безнадежно устарел. Так ли это? Попробуем дать свой ответ на данный вопрос, избегая категоричности, и, уж, тем более, изречения истин в последней инстанции.

Стратегия и логика исторического исследования настоятельно диктует начать освещение указанной выше темы с раскрытия сущности и содержания такого термина как класcы. И здесь мы вторгаемся в научную сферу, которую можно классифицировать как «история мысли». Но без такого вторжения невозможно обойтись при раскрытии предмета нашего исследования. «Я не знаю общества свободного от идей, как бы мало оно ни было развито. Само общество - это уже идея, потому что общество начинает существовать с той минуты, как люди, его составляющие, начинают сознавать, что они - общество. Ещё труднее мне подумать, что идеи лишены участия в историческом процессе» [10, с. 53], - писал великий русский историк В.О. Ключевский. А выдающийся советский историк М.В. Нечкина, как бы развивая мысли В.О. Ключевского, творчество которого она в свое время глубоко исследовала [11] (разумеется, в теоретико-методологической системе координат догматизированного марксизма-ленинизма в большевистском его измерении), отмечала, что без истории мысли «наука превращается в груду фактов, а история науки - в простую библиографию предмета» [12, с. 8].

Следует подчеркнуть, что для К. Маркса и Ф. Энгельса уже на стадии ранней разработки своего учения стало ясным, что классы в процессе своего формирования и развития вступают в борьбу между собой. Ф. Энгельс писал: «...вся история человечества (со времени разложения первобытного родового общества с его общинным землевладением) была историей борьбы классов, борьбы между эксплуатирующими и эксплуатируемыми, господствующими и угнетенными классами...» [1, т. 21, с. 367].

Но для этих мыслителей борьба классов не вечна. Она приведет, конечном счете, к диктатуре пролетариата, а затем к построению бесклассового общества: «То, что я сделал нового, - отмечал К. Маркс, состояло в доказательстве следующего: 1) что существование классов связано лишь с определенными историческими фазами развития производства ..., 2) что классовая борьба необходимо ведет к диктатуре пролетариата, 3) что эта диктатура сама составляет лишь переход к уничтожению всяких классов и к обществу без классов» ... [1, т. 28, с. 426-427]. К. Маркс (по словам В.И. Ленина), полагал, что необходимо «вскрыть все формы антагонизма и эксплуатации в современном обществе, доказать переходящий характер, неизбежность превращения их в другую форму и послужить таким образом пролетариату, для того, чтобы он как можно скорее и как можно легче покончил со всякой эксплуатацией» $[13$, т. 1, с. 340-341]. Для классиков марксизма является аксиоматичным утверждение об отмирании классов (разумеется, в исторической перспективе). Причем, ускорит это отмирание антагонизм двух главных и последних классов - пролетариата и буржуазии. А затем наступит (в марксовом понимании) бесклассовое коммунистическое общество.

И это стройное логически выверенное концептуальное построение находит свое подтверждение, в какой-то степени, и в XX в., да и в начале XXI в. Например, в Великобритании, в конце 1980-х годов богатейшая элита общества, составляющая $1 \%$ населения, владела $21 \%$ всех личных состояний, в то время как $80 \%$ населения распоряжалось лишь третью национального богатства [14, p. 217]. Да и вряд ли стоит брать под сомнение тезис, выдвигаемый в ряде исследований, что сам объективный процесс движения современного западного общества в направлении большей социальной справедливости и нарастания демократических тенденций выступает в значительной степени результатом предшествующей классовой борьбы [15]. Но, если исходить из современных представлений о научном знании как нелинейной системе, в марксовой концепции, которая рассматривается выше, налицо заидеологизированность, особенно в плане анализа диктатуры пролетариата и исторической перспективы становления бесклассового коммунистического общества. Все концептуальные построения К. Маркса и Ф. Энгельса 
носят глобальный характер, в них не нашлось соответствующего места раскрытию роли и места целых социальных слоев населения. У К. Маркса есть оригинальный синтез о социальной сущности человека, которая не есть абстракт, присущий отдельному индивиду. В своей действительности она есть, совокупность всех общественных отношений» $[1$, т. 3 , с. 3]. И выглядит логичным, что во «всех общественных отношениях» есть ядро - отношения классовые, ибо есть классовое общество. К. Маркс и Ф. Энгельс, в конечном итоге, возвели в абсолют в последующих своих изысканиях их любимое детище - классовую борьбу. Следовательно, ушли далеко на задний план, к примеру, цивилизационные факторы. Кроме того, классики марксизма недооценили диалектику индивидуального в историческом процессе и социальных движениях, а также и в структуре и поведении личности, что прошло незамеченным в современных исследованиях [16, с. 111-123].

«Марксизм есть теоретическое обоснование уничтожения классов» $[13$, т. 40, с. 303], - писал В.И. Ленин. Он являлся не только твердым последователем учения К. Маркса и Ф. Энгельса, но и мыслителем, много сделавшим для его творческого развития. Конечно, В.И. Ленину не удалось расшить узкие места рассматриваемой выше марксисткой концепции. Между тем, он, творчески развивая марксизм, вышел, в конечном итоге, на дефиницию «классы», которая, несмотря на некоторую громоздкость, довольно четко раскрыла сущность и содержание этого понятия. Основатель Советского государства в 1919 г. писал, что классы - это «большие группы людей, различающиеся по их месту в исторически определенной системе общественного производства, по их отношению к средствам производства, по их роли в общественной организации труда, а, следовательно, и по способам получения и размерам той доли общественного богатства, которыми они располагают» [13, т. 39, с. 15].При этом необходимо подчеркнуть, что именно В.И. Ленин выдал четкую и однозначную методологическую посылку к пониманию того, что классовый подход к оценке событий и явлений (в марксистской интерпретации) существует [17]. ОН писал: «Люди всегда были и всегда будут глупенькими жертвами обмана и самообмана в политике, пока они не научатся за любыми нравственными, религиозными, политическими, социальными фразами, заявлениями, обещаниями разыскивать интересы тех или иных классов» $[13$, т. 23, с. 47$]$.

Исходя из подобной ленинской методологической посылки, советские историки вышли на следующее понимание классового подхода: изучать исторические события и процессы, историографические и историографические источники с позиции определенного класса (пролетариата). Такое понимание вырабатывалось под неусыпным контролем лидеров и идеологов правившей в Советском государстве коммунистической партии. Оно нашло даже свое нормативное оформление в партийных документах (в вариантах, несколько отличающихся по форме, но не по содержанию), которые по существующему тогда порядку вещей имели статус основополагающих, принимавшихся к неукоснительному исполнению. Например, в Тезисах Центрального Комитета КПСС «К 100-летию со дня рождения Владимира Ильича Ленина» подчеркивалось, что «главное в ленинском подходе к общественным явлениям и процессам - органическое единство научной объективности и принципиальной оценки их с позиций рабочего класса» $[18$, с. 227-228]. Выглядит закономерным, что классовый подход к оценке событий и явлений усилиями правившей в нашей стране коммунистической партии, не только узаконили в исторической науке, но и возвели его в абсолют $[18 ; 19 ; 20$, с. $3-34 ; 21$, c. 168-183]. А ученых заставили еще и методологически обосновывать подобную абсолютизацию [22; 23].

Однако концепция классового подхода, созданная в советской исторической науке, не была такой стройной, как виделось ее разработчикам и заказчикам. Ее стройности мешало то, ученые в трактовке понятия «классовый подход» элементы эклектики. Так, в 1920-е годы, когда историки творили в условиях относительной творческой свободы, которая уверенно исчезала, понятие «классовый подход» стало отождествляться с понятием «научность исследований» [24]. При этом понятие «классовый подход» как цельная речевая конструкция, как правило, не употреблялось [25, с. 69-116; 26, с. 34-57]. Например, С.Д. Куниский, упрекает Жореса в том, что он не смог провести классового анализа исторических явлений, связанных с течением Великой Французской революции. Поэтому труд Жореса во многом не научен, идеалистичен. А далее С.Д. Куниский утверждает, что существует высшая объективность, это - «объективность историка пролетариата, идеал которого с железной необходимостью создается внутренней логикой исторического процесса» [27, т. 2 , с. $140-158$, т. 3 , с. $117-151$, т. 4, с. 101-124]. Подобная тенденция получила дальнейшее развитие в советской историографии, но только еще и в более тесной связи с принципом партийности [28, с. 3-12].

Об элементах эклектики свидетельствует и то, и то, что на протяжении всего периода развития советской исторической науки постепенно наметилась и оформилась тенденция употреблять термины «классовый подход» и «принцип партийности» чуть ли не в качестве синонимов [29-32; 33, с. 147-155]. Вряд ли это представляется целесообразным. Ведь научный подход - широкое понятие. Исследователь, выбирая подход, определяет первоначальный вектор в работе, то есть он закладывает фундамент своих научных изысканий, базируясь на котором, используя который, он пытается достичь поставленной научной цели. Подход определяет основной путь решения исследовательской задачи. Он раскрывает стратегию этого решения [34; 35]. В то же время, известно, что принцип, с общефилософской точки зрения, представляет собой основание некоторой совокупности фактов или знаний, исходный пункт объяснения или руководства к действиям [36, с. 374]. Выходит, что какие-либо принципы могут быть заложены в основу какого-либо подхода. И, конечно же, принцип партийности является один из тех краеугольных камней, на которых зиждется классовый подход. Так, один из выдающихся советских историков А.И. Зевелев констатировал следующее: «Основываясь на том, что познавательный процесс носит социально-классовый характер и что классовая борьба рассматривается как основа теорий и учений, коммунистическая партийность в историографии дает возможность определить классовую направленность историографических фактов и выявить причины классово-побуждающих мотивов их появления» $[37$, c. $62-63]$. 
Ипполитов Г.М.

Но вряд ли правомочно в данной связи отождествление понятий «классовый подход» и «принцип партийности». Между тем, это отождествление произошло. Причем, главным аргументом здесь послужили цитаты из произведений классиков марксизмаленинизма, которые стали своего рода оружием для цитатных боев, столь модных в советской историографии. Например, вот некоторый набор для цитатных боев того времени: стремления к истине, свойственного подлинным ученым, совпадает с интересами и стремлениями рабочего класса $[1$, т. 21 , c. 317]; история - наука партийная, отражающая борьбу различных общественных сил классового общества $[38$, с. 333$]$; «...вопрос стоит только так: буржуазная или социалистическая идеология. Середины здесь нет» [13, т. 6, с. 39]. Ясно, что ученые сразу ставились в данном случае в жесткие рамки, из которых им было вырваться практически невозможно [39, с. $135-171]$

Между тем, не следует считать, что классовый подход - простое умозрительное построение классиков марксизма. Думается, можно согласиться с мнением В.С. Степина, что марксистская концепция классовой борьбы, социальных революций и диктатуры, как способа решения общественных проблем, возникла в общем контексте ценностей техногенной культуры [40, с. 53]. Однако подобный тезис не может служить оправданием догматизма, имевшего место в марксизме, особенно в большевистском его измерении (ленинизм), который лидеры и идеологии правившей в Советском государстве умело использовали в интересах политического режима советской власти. При этом необходимо подчеркнуть, что в насаждении классового подхода в историческую науку именно догматизм сыграл исключительно важную роль. Ведь догматизм имеет главную характерную черту которого четко определил Г.Ф. Гегель - одностороннее рассудочное мышление, когда «исключаются противоположные определения» [41, c. 70]. Причем, он выступает в тесной связи с конъюнктурщиной, отличающейся от догматизма лишь тем, что она может быть не закостенелой, а постоянно видоизменяться, реагируя на политический ангажемент. В конечно итоге, в советский период развития исторической науки марксизм-ленинизм, став государственным мировоззрением, был огражден от критики. Создали все условия, чтобы тот, вместо утверждения себя в качестве одного из путей исторического познания, окончательно закостенел.

Из-за такой закостенелости, например, встречались выводы об автоматическом преимуществе Советского Союза в военной теории, к военном строительстве, в военном искусстве, о превосходстве советской военной науки над буржуазной. Классовый подход жестко привязывал к экономическому фактору объяснение причин возникновения войн. Между тем, в современной историографии подобные выводы подвергаются аргументированной критике. Ведь, война, отмечают некоторые исследователи, не является только производной от логики классовых политических отношений, она обладает более сложной палитрой причин и целей. В рамках классового подхода нельзя глубоко познать духовные аспекты войн, военного строительства, способов ведения войн. Война придает государству особое состояние, в котором продолжаются перестроенные на военный лад все формы общественного сознания, культурная деятельность, образ жизни народа, традиции. «Роль классовой борьбы (в истории и, тем более, в войнах), необычайно обострившейся в процессе становления капитализма, была значительно преувеличена» [42]. В то же время, нельзя не заметить, что в поздней советской историографии появились попытки разжать тиски догматизированного марксизма-ленинизма, в том числе и в концепции классового подхода. Так, Б.Г. Могильницкий одним из первых высказал мысль, что сегодня коренным теоретическим вопросом, выдвинутым перед марксистским обществоведением самой жизнью, «является вопрос о сочетании классового и общечеловеческого начал в реальном мировом развитии, а, следовательно, и в изучении этого развития исторической наукой» [43, с. 81$]$

Что характерно: несмотря на мощную критику классового подхода, прозвучавшую в постсоветской и современной историографии, исследователи всетаки, в конченом итоге, не смогли вывести его из методологического арсенала историков. Пришлось высказывать в данной связи свое мнение. Так, Г.Д. Алексеева еще в 1993 г. констатировала, что в настоящее время «полностью отвергаются классовые оценки». Однако далее она высказала суждение, что будущее покажет, приемлемо ли такая постановка вопроса, и поможет ли это «вывести нашу науку из кризиса без потери того ценного, что было ею накоплено на протяжении всего XX в.» [44, с. 348].

И на том историографическом поле родилась идея, авторы которой посчитали ее новаторской. Но суть такого новаторства свелась к элементарной подмене понятий, игре в дефиниции. Так, А.В. Бочаров утверждает буквально следующее: «В связи с дискредитацией понятия «партийность» его предпочитают избегать в современной методологии истории. Было введено понятие «ценностный подход», который можно определить как принципиальное требование учёта одним историком влияния мировоззрения других историков на создание образа событий, а также требование рефлексии по поводу собственных мировоззренческих оснований» [45]. Но здесь все та же эклектика: принципы и подходы объявляются тождественными, что далеко не так. А.В. Бочаров выдает также желаемое за действительное, когда утверждает, что в современной методологии истории дефиницию «принцип партийности» предпочитают избегать. Думается, что в учебном пособии такие излишне категоричные суждения, оценки, которые допустил А.В. Бочаров, вряд ли уместны (ведь учебное пособие - это не дискуссионная статья или выступление на научной конференции). Причем, подобная эклектическая мешанина (в контексте игры в дефиниции) получила тогда относительно широкое распространение. Например, дефиницию «партийность» стали заменять новым понятием - «социальный подход». При этом необходимо подчеркнуть, что здесь вернули из кладезя исторической мысли изрядно к тому времени подзабытое положение замечательного русского марксиста Г.В. Плеханова: «Там, где историку приходится изображать борьбу противоположных сил, он неизбежно будет сочувствовать той или другой. В этом отношении он будет субъективен... Но такой субъективизм не помешает ему быть совершенно объективным историком, если только он не станет искажать реальные экономические отношения, на почве которых выросли общественные силы» [46, с. 671] (данная цитата Г.В. Плеханова использована, например, в электронной публикации «Основные принципы научного исторического ис- 
следования» для разъяснения, что такое социальный подход [47]). Другой пример: А.А. Аникеев выделяет среди принципов исторической науки принцип "партийно-классовый" [48, с. 22]. Но буквально на следующей странице он употребляет уже понятие "партийно-классовый подход"» [48, с. 23]. (?!). Тем не менее, подобная игра в дефиниции стала своего симптоматичной в плане пересмотра отношения к классовому подходу как составляющей методологической основы исторических исследований. Например, отдельные авторы считают, что принцип социального подхода предполагает рассмотрение историко-экономических процессов с учетом социальных интересов различных слоев населения, различных форм их проявления в обществе. «Этот принцип (еще его называют принципом классового, партийного подхода - подчеркнуто автором данной ста$m b и$. - Г.И.) обязывает соотносить интересы классовые и узко групповые с общечеловеческими, учитывая субъективный момент в практической деятельности правительств, партий, личностей» [49].

Даже современные ученые, которые декларируют ярко выраженную приверженность к методологии марксизма-ленинизма, защищая классовый подход от нападок [50], сами при этом впадают в противоречия. Так, в обширной статье Ю.И. Чунькова выдвигаются аргументы в защиту классового подхода в марксистско-ленинской его интерпретации [52]. Однако ученый, в конечном итоге, приходит к такому обобщению: «Исследование необходимо проводить не в интересах какого-либо одного класса, а в интересах научной истины. Действительная научная истина лишена классовости» [52]. Подобная позиция явно не соответствует марксистско-ленинскому пониманию защищаемого Ю.И. Чуньковым классового подхода.

И что небезынтересно: в современной историографии появилась и критика новых дефиниций, которыми отдельные ученые попытались заменить понятие «классовый подход». Например, А.Т. Степанищев, констатируя, что сегодня сохраняется в научном обороте понятие «социальный подход», считает, что оно не претендует на научное долголетие, поскольку в нём заложено множество противоречий. «Социальный» - это «обусловленный делением общества на классы». «И, если бы наше общество действительно было чётко разделено на классы, если бы имелись партии, отражающие интересы только конкретных классов, тогда понятие «социальный подход» могло стать жизненным. Но возможно ли в современной России, среди наиболее крупных партий, встретить такую, которая отражала бы интересы какой-то одной социальной группы - рабочих, селян, государственных служащих, торговых работников и т.д.? Даже в КПРФ, объявившей о защите интересов трудящихся, партийные билеты имеет олигарх и рабочий, пенсионер и милиционер, актёр и фермер, академик и писатель и т.д. Поэтому, понятие «партийность», а не «социальный подход», носит более устойчивый характер, поскольку историк-партиец в своём исследовании, вольно или непроизвольно, будет отражать интересы идеологии своей партии, а не интересы каждой из десятков социальных групп, представители которых входят в эту партию», - отмечает, причем, в очень читабельном стиле, А.Т. Степанищев [53]. С таким мнением ученого можно, да и должно, спорить. Между тем, с ним трудно, полагает автор данной статьи, в конечном итоге, не согласится.
Таким образом, классовый подход к оценке событий и явлений сегодня в исторической науке не устарел безнадежно, как считают многие представители так называемой либеральной исторической школы (с В.О. Ключевским прошу не путать), а продолжает функционировать. Правда, изменив формы проявления, и несколько отойдя на задний план. Не станет преувеличением сказать: на современном этапе приращения исторических знаний классовый подход, безусловно, потерял ту значимость, что придавалась ему в советской исторической науке. Его использование вне связи с другими принципами в познании истории видится недостаточным, так как помимо классовых подходов присутствуют общечеловеческие подходы, учитывать которые ученому необходимо. В то же время неправильно полагать, что можно достичь исторической истины, если встать на путь искусственной изоляции исторических исследований от современной социально-политической борьбы. История, как наука, не может развиваться абстрактно вне исторического пространства и времени. Она находится в органическом единстве с социальнополитической ситуацией, имеющей место в стране в тот или иной период ее истории. А это залог того, что классовый подход будет по-прежнему занимать свою нишу в методологическом арсенале ученыхисториков (разумеется, видоизменяя свои формы). Но вот использовать его надо не только творчески, но и осторожно. Иначе возникнет реальная возможность печального повторения пройденного - тиски догматизма (впрочем, последнее суждение применимо к любому из методологических подходов исторической науки, если их возвести в абсолют и не применять комплексно).

\section{Список литературы:}

1. Маркс К., Энгельс Ф. Соч.: В 50 т. Изд. второе. М.: Издательство политической литературы, 19551981.

2. Гуревич А.О. О кризисе современной исторической науки // Вопросы истории. 1991. № 2-3. С. 21-36.

3. Данилов В.Л. Современная российская историография: в чем выход из кризиса // Новая и новейшая история. 1993. № 6. С. 95-101.

4. Алексеева Т.Д. Историческая наука России в поисках новых концепций Россия в XX веке: Историки мира спорят: Сб. ст. М.: Наука, 1994. С. 635-642.

5. Корзун В.П. Образы исторической науки на рубеже XIX-XX вв.: (Анализ отечеств. историогр. Исслед.). Екатеринбург: Изд-во Ур. ун-та; Омск: ОмГУ, 2000. $226 \mathrm{c}$.

6. Поляков Ю. Наше непредсказуемое прошлое. М.: АИРО-ХХ, 1995. 216 c.

7. Ипполитов Г.М. Принцип партийности исторической науки: неактуальное наследие советских времен или сегодняшняя методологическая данность? (дискуссионные заметки) // Известия Самарского научного центра РАН. 2015. Т. 17, № 3 (2). С. 475-484.

8. Сахаров А.Н. О новых подходах к истории России // Вопросы истории 2002. № 8. С. 3-20.

9. Искандеров А. Два взгляда на историю // Вопросы истории. 2005. № 4. С. 3-32.

10. Ключевский В.О. Соч. Т. І. Курс русской истории. М.: Мысль, 1987. 432 с.

11. Нечкина М.В. Василий Осипович Ключевский. История жизни и творчества: монография. М.: Наука, 1974. $640 \mathrm{c}$. 
12. Нечкина М.В. История истории (Некоторые методологические вопросы истории исторической науки) // История и историки. Историография истории СССР: сб. статей. М.: Наука, 1965. С. 6-28.

13. Ленин В.И. Полн. собр. соч.: в 55 т. М.: Издательство политической литературы, 1967-1981.

14. Yidens A. Sociology. Cambridge, 1989, 217 p.

15. Крапивенский С., Косицина Ф. Марксистский классовый подход: проблемы обновления и точки развития [Электронный ресурс] // Материалистическая диалектика. - http://libelli.ru/magazine/96_4/approach.htm.

16. Ковальченко И.Д. Историческое познание: индивидуальное, социальное и общечеловеческое // Свободная мысль, 1995. № 2. С. 111-123.

17. Главное в ленинизме (В.И. Ленин о классовом подходе к анализу общественных явлений) / сост. М.В. Попов. СПб.: Изд-во Политехн. ун-та, 2009. 311 с.

18. Вопросы идеологической работы КПСС. Сборник документов (1965-1973 гг.). Изд. 2-ое, доп., М.: Политиздат, 1973. С. 227-228.

19. О мерах улучшения подготовки научно-педагогических кадров по историческим наукам: всесоюз. совещ., 18-21 дек. 1962 г. М.: Наука, 1964. 517 с.

20. Обсуждение вопросов методологии истории на расширенных заседаниях секции общественных наук президиума АН СССР 3 и 6 января 1964 года // Вопросы истории. 1964. № 5. С. 3-34.

21. Пономарев Б.Н. Задачи исторической науки и подготовка научно-педагогических кадров в области истории // Пономарев Б. Избранные речи и статьи. M., 1977. C. $168-183$.

22. Кедров Б.М. В.И. Ленин и методологические вопросы исторической науки. М.: Знание, 1969. 64 с.

23. Маслов Н.А. Марксистско-ленинские методы историко-партийного исследования. М.: Мысль, 1983. $157 \mathrm{c}$.

24. Сидоров А.В. Принцип научности в марксистской историографии 1920-х годов [Электронный ресурс] // Государственное управление. Электронный вестник. 2012. Вып. № 30. - http://e-journal.spa.msu. ru/uploads/vestnik/2012/vipusk_30._fevral_2012_g./iz_ istorii_upravlenija/sidorov.pdf.

25. Газганов Э. Исторические взгляды Г.В. Плеханова // Историк-марксист. Т. 7. 1928. С. 69-116.

26. Горин П.М. Н. Покровский как историк первой русской революции // Историк-марксист. Т. 9. 1928. С. 34-57.

27. Куниский С.Д. Жорес - историк // Историк марксист. Т. 2. 1926. С. 140-158; Т. 3. 1927. С. $117-$ $151 ;$ T. 4. 1927. C. $101-124$.

28. Ленинский принцип партийности и научная объективность // Средние века. 1980. Вып. 43. С. 3-12.

29. Жуков Е.М. Очерки методологии истории. М.: Наука, 1980. 250 с.

30. Бурмистров Н.А. Классовая природа партийности исторической науки (Теория и практика исследования). Казань: Изд-во Казан. ун-та, 1989. 182 с.

31. Методологические проблемы историко-партийной науки / под общ. ред. Н.Н. Маслова и П.М. Шоргуна. Киев: Вишца школа, Изд-во при Киев. гос. унте, 1976. $256 \mathrm{c}$.

32. Варшавчик М.А., Спирин Л.М. О научных основах изучения истории КПСС: (Введение в историко-партийную науку). М.: Политиздат, 1978. 191 с.

33. Маслов Н.А. Усиление внимания к проблемам методологии, историографии и источниковедения - важное условие дальнейшего развития историко-партийной науки // Вопросы истории КПСС. 1982. № 3. C. $147-155$.

34. Поппер К.Р. Объективное знание. Эволюционный подход / пер. с англ. Д.Г. Лахути; отв. ред. В.Н. Садовский. М.: Эдиториал УРСС, 2002. 384 с.

35. Степин В.С. Теоретическое знание. Структуpa, исторические типы. М.: Прогресс: Традиция, 2000. $744 \mathrm{c}$.

36. Социология: Энциклопедия / сост. А.А. Грицанов, В.Л. Абушенко, Г.М. Евелькин, Г.Н. Соколова, О.В. Терещенко. Минск: Интерпрессервис; Книжный Дом, 2003. 1312 с.

37. Зевелев А.И. Историографическое исследование: методологические аспекты. М.: Высшая школа, 1987. $160 \mathrm{c}$.

38. Энгельс - теоретик. М.: Изд-во политической литературы, 1970. 200 с.

39. Сидорова Л.А. «Руководящая цитата» в советской исторической науке середины XX в. // История и историки. 2006. Историографический вестник. М., 2007. C. $135-171$.

40. Степин В.С. Философская антропология и философия науки. М.: Высшая школа, 1992. 191 с.

41. Гегель. Энциклопедия философских наук. Ч. 1. Логика. М.; Л.: Государственное издательство, 1929. $437 \mathrm{c}$.

42. Добреньков В.И., Агапов П.В. Война и безопасность России в XXI веке [Электронный ресурс] // Обозник. История тыла Российской армии. Информационно-тематический портал. - http://oboznik.ru/?p=13345.

43. Могильницкий Б.Г. Введение в методологию истории. М.: Высшая школа, 1989. 191 с.

44. Алексеева Г.Д. Поиски выхода из кризиса исторической науки: традиции и новации // Историческое познание: традиции и новации: мат-лы междунар. теор. конф. Ижевск, 26-28 окт. 1993 г. Ч. 1. Ижевск: Изд-во Удмуртского университета, 1996. С. 344-352.

45. Бочаров А.В. Алгоритмы использования основных научных методов в конкретно-историческом исследовании: учебное пособие. Томск, 2007.

46. Плеханов Г.В. Избранные философские произведения. Т. 1. М., 1956. 845 с.

47. Основные принципы научного исторического исследования [Электронный ресурс] // Страницы истории. - http://storyo.ru/munchaev/04.htm.

48. Аникеев А.А. Методология классической историографии. учебное пособие. Ставрополь: Сервизшкола, 2005. 152 с.

49. Всемирная история. учебник для вузов. Вводная глава. М., 1997.

50. Бударин В.А. Против извращений методологии классового подхода [Электронный ресурс] // Politpros.com. Журнал «Политическое просвещение. 2013. № 6 (77). http://politpros.com/journal/read/?ID=2813\&journal=132.

51. Огородников В.П. В.И. Ленин и классовый подход к проблемам современной России [Электронный pecypc] // Ленин: вождь, мыслитель, человек. - https:// leninism.su/lenin-now/4187-lenin-v-sovremennom-mire2010.html? start $=15$.

52. Чуньков Ю.И. Классы и классовый подход: без идеологических сантиментов и предметно // Экономическая и философская газета. 2013. № 21-22.

53. Степанищев А.Т. Принцип партийности в исследовании и преподавании истории [Электронный pecypc] // Чекист.RU. Информационно-аналитическое издание. - http://chekist.ru/article/2706. 


\section{IS A CLASS APPROACH TO LEARN HISTORY OUT OF DATE? OR ... (INVITATION TO A DISCUSSION)}

(C) 2019

Ippolitov Georgiy Mikhailovich, doctor of historical sciences, professor of Philosophy Department Povolzhskiy State University of Telecommunications and Informatics (Samara, Russian Federation)

Abstract. In the following paper the author disclosures some aspects of a complex problem. It is a class approach to the assessment of events and phenomena as one of the approaches to learn history. The style is lapidary, with conciseness elements. The author considers fundamental postulates of the Marxist-Leninist concept of a class approach to the assessment of events and phenomena as one of the approaches to learn history. The emphasis is placed here on Lenin's understanding of the methodological phenomenon stated above and its development by ideologists of the Communist Party governing the Soviet state. Development of the studied concept in the Soviet historical science is traced. At the same time it is emphasized that eclecticism elements were allowed when scientists confused the concepts «principles of a historical research» and «approaches to learn history». The author considers how the problem of a class approach to assessment of events and phenomena is treated in a Post-Soviet and modern historiography. The author says that this approach hasn't become outdated in historical science as many representatives of so-called liberal historical school consider (don't confuse with V.O. Klyuchevsky) and continues to function. However, it changed manifestation forms and receded a little into the background.

Keywords: class approach; K. Marx; F. Engels; V.I. Lenin; soviet historical science; Marxism-Leninism; social approach; game of definitions.

УДК 930.1

DOI 10.24411/2309-4370-2019-12234

Статья поступила в редакцию 22.01.2019

\section{ТРАНСФОРМАЦИИ ОЦЕНОК ИСТОРИЧЕСКИХ СОБЫТИЙ И ФАКТОВ В КОНТЕКСТЕ СОЦИОКУЛЬТУРНОГО ВЛИЯНИЯ СОВРЕМЕННОСТИ}

(C) 2019

Ипполитова Анастасия Георгиевна, кандидат культурологии, доцент, профессор кафедры философии и общегуманитарных дисциплин Самарский юридический институт ФСИН России (2. Самара, Российская Федераџия)

Аннотация. В статье показаны трансформации отношения к историческим событиям, фактам и персоналиям в контексте влияния парадигм мышления современной социокультурной обстановке. Объективность исторической науки - вещь подвижная, ведь сама история - органичная часть культуры, отражающая в своих интерпретациях её менталитет и ценностные ориентации, важные для социума в данный отрезок времени. Исторический процесс - живой культурный поток, наполненный уникальными знаками и символами, способами демонстрации в культуре. Современность определяет отношение общества к историческому процессу, значимость персоналий, их популярность. Здесь историческая оценка становится отражением современных реалий. Мы не можем во всей полноте ощутить на себе влияния исторического персонажа, только вообразить. Примеряем на себя образы прошлого, немного фантазируем, наделяем эмоциями и чувствами, «включая» субъективность восприятия исторических событий в современности. Общество проводит исторические параллели, оценивает прошлое с позиции понятной ему парадигмы мышления, что и приводит к трансформации исторических оценок в различные исторические периоды. Все сказанное выше, безусловно, характерно для трансформационного процесса отечественной истории, что показано на ряде примеров. Они отражают не позицию автора, а именно интерпретацию, характерную для современного социума. Особое внимание уделено оценке Великой Отечественной войны, память о которой необходима для укрепления единства общества и трансляции патриотических ценностей.

Ключевые слова: история; культура; кризис культуры; объективность исторической науки; историческая персоналия; историческое событие; социокультурная трансформация; миф; мифологизация истории; парадигма мышления; К. Леви-Стросс; Т. Лессинг; Великая Отечественная война; монголо-татары; И.В. Сталин; Николай II.

История - наука, которой должна быть присуща объективность, строгий подход. Одновременно это очень гибкая форма знания, на которую накладывает отпечаток современность и ее ценностные установки, социальная обстановка и массовые суждения. Иными словами, культура конкретного отрезка времени, ментальность социумов оказывает непосредственное влияние на оценку исторических событий и фактов. В таком смысле история предстает перед нами феноменом культуры, ее органической частью. А содержание и смысл исторического процесса при- вносится интерпретаторами истории [1, с. 283]. В повседневности она ассоциируется с воспоминаниями, которые необходимы любому. Еще К. Леви-Стросс заметил «Воспоминание - великое наслаждение для человека, но только не тогда, когда оно оказывается буквальным» [2, с. 83-84]. Однако именно в процессе воспоминаний и обнаруживается опасность трактовать историю буквально, перенося на нее картину мира современности и личные пристрастия. Здесь и обнаруживаются трансформации интерпретаций и частичная потеря объективного взгляда. 